\title{
Yes we can! Exciting progress and prospects for controlling invasives on islands and beyond
}

\author{
Daniel Simberloff ${ }^{1, *}$, Brad KeitT $^{2,5}$, David Will ${ }^{2}$, \\ Nick Holmes ${ }^{2}$, Erin PicketT ${ }^{2,3}$, and Piero Genovesi ${ }^{4}$ \\ ${ }^{1}$ Department of Ecology and Evolutionary Biology, University of Tennessee, Knoxville, TN \\ ${ }^{2}$ Island Conservation, 2100 Delaware Ave., Suite 1, Santa Cruz, CA 95060 \\ ${ }^{3}$ Present address: Hatfield Marine Science Center, Oregon State University, Newport, OR \\ ${ }^{4}$ Institute for Environmental Protection and Research, Rome, Italy \\ 5Present address: American Bird Conservancy, Box 249, The Plains, VA 20198
}

\begin{abstract}
Eradication and maintenance management of island invasive species have long histories, and incremental improvements of existing technologies plus occasional novel approaches have led to more challenging targets and increased success rates in certain categories. Many nonnative mammals have been eradicated from islands, as have several nonnative birds, insects, and plants. Hundreds of rat populations have been eliminated, with a success rate over $80 \%$, and islands over 10,000 ha are now feasible targets. Mouse eradication has proven more challenging, but aerial broadcast of anticoagulant toxins has led to increased success. Carnivore eradication-especially of feral housecats and foxes—has been frequently attempted with a recent success rate over $90 \%$. Eradication of herbivores-primarily goats, rabbits, wild boar, and boar/pig hybrids - has been attempted almost 200 times, with a success rate over $90 \%$. Trends in mammal eradication include more frequent attempts and higher success rates on larger islands and inhabited islands, as well as attempts targeting multiple invasive species. Documented conservation gains from island mammal eradications are numerous. For insects, about two-thirds of some 50 island attempts have succeeded, and most targeted agricultural pests. No summary statistics exist on island plant eradications, but several small infestations have been eradicated. Several insect and plant island invaders have been maintained at low densities by biological control, and plants have been controlled short of eradication by herbicides, often combined with physical or mechanical means. Failures in both eradication and maintenance management on islands often result from insufficient long-term commitment of resources. Excitement and controversy abound over the prospect that new techniques relying on molecular genetic tools—especially RNA-guided gene drives-may permit eradication or maintenance management of nonnative invaders in situations that have previously appeared extremely difficult or infeasible. Island populations of invertebrates, small mammals, and some plants are particularly propitious targets.
\end{abstract}

Resumen.-La erradicación y la gestión de la conservación de las especies invasoras de islas tienen una larga historia, y la optimización gradual de las tecnologías existentes junto con nuevos enfoques han llevado a objetivos más desafiantes y a un incremento en la tasa de éxito en ciertas categorías. Muchos mamíferos alóctonos han sido erradicados de las islas, al igual que muchas aves, insectos y plantas no nativas. Cientos de poblaciones de ratas han sido eliminadas, con una tasa de éxito superior al 80\%, y las islas de más de 10,000 hectáreas se volvieron objetivos viables. La erradicación del ratón, ha representado un mayor reto, sin embargo, el subministro aéreo de toxinas anticoagulantes ha llevado a incrementar el éxito de erradicación. La erradicación de carnívoros, especialmente de gatos domésticos ferales y zorros se ha procurado en reiteradas ocasiones, con una tasa de éxito reciente de más del $90 \%$. Por otra parte, la erradicación de herbívoros, principalmente de cabras, conejos, jabalíes e híbridos de jabalí/cerdo, se ha llevada a cabo en alrededor de 200 ocasiones, con una tasa de éxito superior al $90 \%$. Las tendencias en la erradicación de mamíferos incluyen acciones más frecuentes y mayor tasa de éxito en las islas de mayor tamaño y en islas habitadas, así como, acciones teniendo como objetivo múltiples especies invasoras. Los beneficios de la erradicación de mamíferos isleños son numerosos. En cuanto a los insectos, aproximadamente dos tercios de las 50 tentativas de erradicación en islas tuvieron éxito, la mayoría de plagas agrícolas. No existen informes estadísticos sobre la erradicación de las plantas de las islas, pero se han logrado erradicar varias infestaciones pequeñas. Muchos insectos y plantas invasoras se han mantenido en bajas densidades por medio de control biológico, las plantas han sido controladas con herbicidas, frecuentemente combinando con el uso de medios físicos o mecánicos, sin necesidad de erradicarlas. Las fallas tanto en la erradicación como en la gestión de la conservación, con frecuencia, son resultado de una asignación de recursos insuficientes a largo plazo. La posibilidad de que nuevas técnicas basadas en herramientas genéticas moleculares (especialmente las unidades de genes guiadas por ARN) permitan la erradicación o la gestión de la conservación de especies invasoras, en situaciones que anteriormente parecían extremadamente difíciles o inviables, generan una gran conmoción y controversia. Las poblaciones insulares de invertebrados, pequeños mamíferos y algunas plantas son objetivos particularmente propicios.

*Corresponding author: dsimberloff@utk.edu 
Realization that introduced species could damage native species and ecosystems came late. Early naturalist-explorers who worked to establish the broad biogeography of the earth and who recognized that some species were not native to some sites they inhabited simply noted the presence of those species (Simberloff 2013a). Probably the first to note a huge impact on islands was Joseph Hooker, who lamented the devastation of several island floras by introduced livestock and European plants (Hooker 1867). Alfred Russell Wallace raised the same concern about Saint Helena (Wallace 1880). In the early 20th century, still well before the impacts of nonnative species were widely seen as a concern, James D. Ritchie (1920) described the impact of introduced species, particularly in Scotland, but he also deplored, in less detail, impacts on other islands such as Mauritius. Contemporarily, George M. Thomson (1922) described impacts of introduced species on the native flora and fauna of New Zealand. Charles Elton (1958), in his popular book The Ecology of Invasions by Animals and Plants, featured ecological impacts of invaders on the Hawaiian Islands, New Zealand, Tristan da Cunha, Easter Island, and other islands. Elton's book did not trigger the burgeoning research that constitutes modern invasion biology. Rather, this field exploded in the wake of a 1980s project convened by SCOPE (Scientific Committee on Problems of the Environment, an arm of the International Council of Scientific Unions) under the leadership of Harold Mooney (Simberloff 2011a). Many SCOPE participants recalled having read Elton's book, and the impact of invasions on islands has been a major component of the field ever since (Simberloff 2011b).

Improved control of invasives was one of the SCOPE project's 3 goals (Simberloff 2011a), but this turned out not to be a major focus of publications resulting from the project. The emphasis was instead on the other 2 goals: determining why certain species seem particularly invasive and why certain sites, such as islands, appear to be more readily invaded. For example, the synthesis SCOPE volume (Drake et al. 1989) contained 22 chapters, of which only 4 treated management. The widely read North American volume (Mooney and Drake 1986) contained only one chapter (of 16) on management, in which Dahlsten (1986) inveighed against eradication programs for introduced insects in favor of biological control.

Dahlsten (1986) and other skeptics were likely influenced by several costly, high-profile failed continental eradication attempts that inflicted enormous nontarget impacts, particularly projects in the United States aimed at the gypsy moth (Spear 2005) in the 19th century and the red imported fire ant (Buhs 2004) and white pine blister rust (Maloy 1997) in the 20th century. However, even before the SCOPE project, successful programs had both eradicated some introduced populations and maintained others at less damaging levels, and islands featured prominently in such efforts. The SCOPE participants seemed not as aware of many of these successes as they might have been, perhaps because they were largely academics focused on ecology and conservation rather than scientists focused on managing specific problems related primarily to agriculture and public health. Probably the earliest insect eradication was the elimination from the island of Príncipe of a long-established population of tsetse fly, Glossina sp., between 1911 and 1914; a reinvasion in 1956 was also eradicated (Lapeyssonie 1988). Between 1934 and 1937, the citrus blackfly (Aleurocanthus woglumi) was eradicated from a several-block area of Key West (Hoelmer and Grace 1989). The New World screwworm fly (Cochliomyia hominivorax) was eradicated during 1954/1955 on the island of Curaçao through use of the revolutionary sterile-male technique (Baumhover et al. 1955), which subsequently found wide application both on islands and the mainland. The recently compiled Database of Island Invasive Species Eradications (DIISE; Keitt et al. 2011, DIISE Partners 2014), a project that aims to tabulate all island-wide vertebrate eradication attempts and their outcomes, identifies many eradications of introduced mammals from entire islands before the SCOPE project. For instance, the Norway rat (Rattus norvegicus) was eradicated from Flatey in 1971 (Petersen 1979), the domestic cat from Aride Island in 1932 (Watson et al. 1992), and goats from Ascension Island soon after World War II (Ashmole et al. 1994). In fact, before 1970 there were at least 5 wholeisland eradications of rats, 6 of cats, 26 of goats, 14 of rabbits, and 16 of boar, feral pigs, and their hybrids. Thus, in retrospect, the pessimism among conservationists regarding 
eradication in the wake of the SCOPE project was overblown.

Pessimism about eradication has sometimes led to the view that, if eradication fails, the battle against an invader is lost (e.g., Vince 2011). However, invaders can sometimes be maintained at low enough levels to minimize ecological damage. The 3 major approaches to maintenance management are mechanical or physical control, chemical control, and biological control (Clout and Williams 2009, Simberloff 2013b). On continents, several invasive plants and animals have been maintained at low levels for extended periods by hand and/or machine, sometimes in combination with chemical control, but there do not appear to be successful island examples, despite some massive efforts. For example, between 1902 and 1908 on Trinidad, 30,895 individuals of the small Indian mongoose (Herpestes auropunctatus) were removed by trapping and hunting in an aggressive bounty program; the same program yielded 142,324 individuals between 1927 and 1930, with no detectable population impact (Urich 1931). In light of the difficulties of island-wide eradication on large islands, a number of projects now entail "mainland islands," areas (often large ones) from which all of one or more target invaders are removed, with reinvasion precluded by fencing. Perhaps most striking among several such projects in New Zealand is Maungatautari, a mountain and surrounding area of 3400 ha on the North Island from which 14 nonnative mammals were removed; only the house mouse (Mus musculus) persists (Innes and Saunders 2011). In the Hawaiian Islands, the goal of island-wide control of feral pigs has been abandoned in favor of control within several large fenced areas in which the goal is removal followed by sustained monitoring with zero detections (T. Menard, personal communication, 2017).

It was many pre-SCOPE continental examples of nontarget impacts of attempted longterm control by chemicals (sometimes as a sort of consolation prize for a failed eradication attempt) and one island example (DDT impact on cutthroat trout [Oncorhynchus clarkii] on Vancouver Island in 1957) that inspired Rachel Carson's Silent Spring (Carson 1962).
Major efforts to reduce nontarget impacts of herbicides and pesticides have been a prominent feature of maintenance management since Silent Spring, with some success, but problems persist and efforts continue (DiTomaso 2011, Herms and McCullough 2011, Whisson 2011, Yadav and Singh 2011). Several early biological control introductions on islands had nearly legendary nontarget impacts. These include introduction of the small Indian mongoose to islands worldwide (Barun et al. 2011), the cane toad (Rhinella marina) to Australia (Lever 2001), the rosy wolfsnail (Euglandina rosea) to many Pacific islands (Civeyrel and Simberloff 1996), and the cactus moth (Cactoblastis cactorum) to Nevis (Pemberton and Liu 2007). These cases were key stimuli for advances in biological control technologies, including greater target selectivity (Van Driesche et al. 2008, 2016).

In sum, during the SCOPE project and in the succeeding decade, invasion scientists were largely pessimistic about the prospects for eradicating invaders on islands or continents, perhaps unjustifiably. Similarly, acceptable means of long-term mainenance management of invasions seemed a difficult goal, largely because of nontarget impacts and expense. Nevertheless, many workers continued to try to achieve eradication or at least long-term control by a plethora of venerable techniques, many modifications of these, and several new approaches, especially in attempts to manage introduced mammals on islands. Below we describe attempts to eradicate various taxa on islands, as well as various maintenance management efforts.

\section{ERADication \\ Mammals}

A scan in early 2014 of the DIISE database yielded $1086^{\mathrm{a}}$ mammal eradication attempts on 693 islands targeting 6 rodent species, 12 herbivore species, and 13 carnivore species. Of these, 125 projects targeted more than one species, and we tallied an attempt on each species as a separate attempt. Of these 1086 attempts, $924(85 \%)$ succeeded, with a dramatic recent increase in frequency of eradication attempts: 67\% occurred after 1995. The

aData were accessed in April 2014 and included events with data quality classified as good or satisfactory, and status as failed, successful, or successful-reinvaded. We included only whole-island eradications for mammals but whole-island and restrictedrange events for birds. 
increase is driven particularly by a surge in the number of rat eradication attempts and a proportionally similar (but numerically much smaller) increase in the number of mouse eradication attempts. The recent (defined as post-1995) success rate, $84 \%$, does not differ significantly from the overall rate. However, substantial differences exist among the overall success rates of the different groups and in how these success rates have changed through time.

For rodents, 617 attempts targeted one of 5 rat species, and several projects included attempts to eradicate more than one species. The other targeted rodent (78 attempts) was the house mouse (Mus musculus). For rats, all but 3 of the 617 eradication attempts on 478 islands targeted the Norway rat (Rattus norvegicus), black rat (Rattus rattus), or Pacific rat (Rattus exulans). Few attempts occurred before the 1980s, which saw a sharp increase in the number of successful attempts per decade; $76 \%$ of rat eradication attempts have occurred after 1995. The greatest number have been on small islands- $45 \%$ on islands smaller than 100 ha. But the number of successes on large islands has increased substantially, with the largest successful eradications so far being those of the black rat on 12,800-ha Macquarie Island, Australia (Beavis and Junt 2014), and the Norway rat on 11,330-ha Campbell Island, New Zealand (Towns and Broome 2003). It is noteworthy that, since 2014, operations have been completed to remove Norway rats and house mice from South Georgia Island in the Atlantic. This project included 9 separate treatment areas (continuous bays and peninsulas separated by glaciers; mice were in only one treatment area), the largest of which is 30,822 ha. The next stage is to determine whether success has been achieved (South Georgia Heritage Trust 2016). Overall, the success rate for island rat eradications has been $84 \%(n=$ $617)$. Success rates on tropical islands are substantially lower than on other islands (Russell and Holmes 2015).

For the house mouse, $69 \%$ of the 78 attempts on 68 islands succeeded, and as with rats, few attempts preceded 1980. Operations in some of these 78 eradication attempts also targeted Rattus species, and several of these attempts were not designed specifically to target mice. Since 2005, all but one of the 16 eradication efforts that targeted mice using aerial broadcast of anticoagulant toxins have succeeded, including the successful 2011 effort on 12,800-ha Macquarie Island, the largest island from which the house mouse, or any rodent, has been eradicated. All 11 mouse eradication attempts in the current decade have succeeded, an increase over the rate of $64 \%$ before this decade. Most of the 78 attempts (95\%) have been on islands smaller than 1000 ha. Feasibility studies for mouse eradication have been completed for much larger islands, such as Gough Island (Parkes 2008) and Marion Island (https://www.birdlife .org.za/conservation/seabird-conservation/ marion-island-appeal, accessed 25 September 2017).

For carnivores, 88 of 175 attempts on 146 islands targeted the house cat (Felis domesticus), while another 31 targeted one of 3 fox species. Several successful eradications of carnivores occurred before a sharp increase in attempts in the 1980s, and successes are most common on larger islands, between 100 and 10,000 ha. The largest island to date on which a carnivore has been eradicated is 102,560 -ha Hiiumaa, Estonia, where an American mink (Neovison vison) eradication ended in 1999 (Macdonald and Harrington 2003). Eradications targeting American mink, whose range is mostly restricted to riparian areas, are among the larger-scale carnivore eradication attempts; a mink eradication attempt is in progress on $\sim 217,000$-ha Lewis and Harris, Scotland (Scottish Natural Heritage 2013). The next large-scale carnivore eradication was removal of arctic foxes (Vulpes lagopus) from 90,500-ha Attu, Alaska (Thomson and Ebbert 2005). For carnivores, the success rate increased with the sharp increase in number of attempts in the 1980s, with a success rate before the 1980 s of $59 \%$ and a subsequent rate of $92 \%$. The overall success rate for carnivore eradications has been $87 \%$; post-1995 the success rate has been $92 \%$; through 1995 it was $81 \%(n=101)$.

The main targeted herbivores have been the goat (Capra hircus), European rabbit (Oryctolagus cuniculus), and wild boar or pig (Sus scrofa), with 74, 64, and 19 attempts, respectively, of 193 total for 12 species on 143 islands. The first such attempt was probably the eradication of feral pigs on Bermuda in 1630 (but note that we did not include this case in our analysis because it did not meet 
DIISE data-quality standards). A major increase in attempts began in the 1950s. For herbivores, the success rate has been consistently high (94\% overall, $95 \%$ post-1995 $[n=$ 87]), and although more attempts have been made on islands between 100 and 1000 ha, many attempts have been made on much larger islands, particularly in the last 2 decades. The largest island on which an herbivore was successfully eradicated is Santiago $(58,465 \mathrm{ha})$ in the Galápagos Islands, Ecuador, where pigs were eliminated by 2000 (Cruz et al. 2005). Even larger islands have had successful eradications of invasions that were not islandwide-for example, Cyprus ( 925,000 ha), from which wild boar were eliminated by 2004 (Hadjisterkotis and Heise-Pavlov 2006), and Isabela in the Galápagos Islands $(458,812 \mathrm{ha})$, where goats were eliminated from the entire northern part of the island ( 250,000 ha) in an attempt ending in 2006 (Carrion et al. 2011). In the California Channel Islands, aside from goats, rabbits, and boar, successful eradications have removed sheep, mule deer, elk, donkeys, cattle, and horses from various islands (CDFW 2015).

INCREASING COMPLEXITY OF MAMMAL ERADICATIONS.-Not only have the number of mammal eradication attempts and frequency of success increased, but the scope and complexity of the projects have increased. We consider an attempt part of a multispecies eradication project if more than one species was targeted within a 2-year period on the same island. Of the 1086 eradication attempts analyzed, 292 were parts of 125 multispecies projects on 120 islands. Of these multispecies projects, 119 succeeded in eliminating at least one target and 102 eliminated all targeted species. Thus, 221 multispecies eradication projects were partially or completely successful. Twenty-nine of these multispecies projects targeted more than 2 species, and one project (on Rangitoto and Motutapu, New Zealand) eradicated all 8 targeted species (Griffiths et al. 2012). Multispecies projects were relatively uncommon through the 1960s but became much more frequent beginning in the 1970s. At least $20 \%$ of all eradication attempts in every decade from the 1970s onward were parts of multispecies projects, and 109 such projects have been mounted since 1990. One or more rat species were targets of 104 of these multispecies projects-indeed, 39 of them targeted only 2 or 3 rat species. However, 35 of the projects targeting rats also targeted mice, and 45 of them targeted other mammals or a bird. Multispecies eradication projects tended to be on smaller islands, averaging 1334 ha compared to 3501 ha for average island size in single-target eradication attempts.

Oppel et al. (2011) and Glen et al. (2013) have reviewed challenges and outcomes of eradication attempts on inhabited islands. In our analysis we define an inhabited island as one either permanently or seasonally inhabited by humans who stay overnight, as determined by a literature review, Wikipedia, and Google Earth satellite imagery depicting buildings. A total of 194 eradication attempts have been mounted on 94 inhabited islands (as previously, a multispecies project on an inhabited island is counted multiple times, once for each species). Of these 194 attempts, 64 were part of 24 multispecies projects on 22 islands; $86 \%$ of these multispecies projects on inhabited islands were undertaken after 1990. For carnivores, herbivores, and birds the numbers of eradication attempts on inhabited islands are 47,59 , and 10 , respectively. Seventy-eight targeted rodents, of which 65 targeted rats. Through the 1970s, the proportion of eradication attempts on inhabited islands was $27 \%$; since then it has fallen to $17 \%$ of the 1086 total attempts. However, because $91 \%$ of all eradication attempts were post-1980, this is when the greatest number of attempts on inhabited islands has occurred. There was a sharp uptick in the number of attempted eradications on inhabited islands in 1960 for all species except for rodents, and in 1990 there was also an uptick for rodents. Average area of targeted inhabited islands was 11,508 ha, whereas average area of targeted uninhabited islands was only 748 ha.

\section{Birds}

Our analysis showed that 8 species of birds have been eradicated in 23 attempts on 21 islands (14 since 1995), with a success rate of 83\%. The Weka (Gallirallus australis) or Common Myna (Acridotheres tristis) were targeted in $68 \%$ of the successes. Ten of the successes were on islands $<100$ ha, but 5 have been on islands $>10,000$ ha; the largest was the Spanish Balearic island Menorca ( 70,000 ha), where the Ruddy Duck (Oxyura jamaicensis) was eradicated from riparian habitats in 2001 
(Genovesi and Carnevali 2011). Notable successes since 2014, when our statistical analysis ended, include the largest whole-island eradications for flying birds: the Red-whiskered Bulbul (Pycnonotus jocosus) from 1100-ha Assumption Island, Seychelles (Anonymous 2015), and the Wild Turkey (Meleagris gallopavo) from 25,000-ha Santa Cruz Island, California (Morrison et al. 2016).

Insects

No analog to DIISE exists for insect eradications, but the Global Eradication and Response Database (GERDA) for arthropod pests and pathogens (Tobin et al. 2014, Kean et al. 2017) tabulates 970 attempts against 308 taxa, of which 165 targeted arthropods. Of these, 54 attempts targeted 16 arthropod species on 47 islands. Of 46 known outcomes, 32 succeeded. Most of these attempts targeted fly pests of agriculture, but others served conservation, such as eradication of the honey bee (Apis mellifera) from Santa Cruz Island in the California Channel Islands (Wenner et al. 2009) and the little fire ant (Wasmannia auropunctata) from Santa Fe Island in the Galápagos Islands (Wetterer and Porter 2003). A partially overlapping data set tabulating 316 ant eradication attempts (Hoffmann et al. 2016) lists 70 attempts on 20 islands, of which half succeeded. The great majority of successes were on very small islands or small sections of larger islands, but larger successes are noted, including the likely eradication of the Argentine ant (Linepithema humile) from approximately 400 ha on Santa Cruz Island in 2013-2014, facilitated by a newly formulated bait (Boser et al. 2014, 2016). As with vertebrate eradications, recent progress has been incremental. There has not been a transformative approach since the development of the sterile insect technique (SIT) in the 1950s (Klassen and Curtis 2005). Most successes have used chemicals, SIT, or both, although the honey bee eradication first used chemicals to destroy many colonies and then employed introduced parasitic varroa mites, achieving an unusual eradication by a biological control agent.

\section{Plants}

Eradication of invasive plants on both islands and mainland has lagged behind that of animals. For example, the proceedings of the 2001 Conference on Eradication of Island
Invasives (Veitch and Clout 2002) reported 59 attempts against animals and only 14 against plants, while the successor conference in 2010 (Veitch et al. 2011) described 129 attempts against animals and 8 against plants. Rejmánek and Pitcairn (2002) were pessimistic about the possiblity of eradicating terrestrial plants unless the target area was extremely small, primarily because of soil seed banks and the expense of monitoring and treating large areas. Nevertheless, invasive plants have occasionally been eradicated from islands, usually small ones (Simberloff 2013c). Rejmánek and Pitcairn (2002) describe 2 eradications of small infestations in the California Channel Islands. Cory and Knapp (2014) and J. Knapp (personal communication 2016) report 32 invasive plant species targeted for eradication on Santa Cruz Island, with approximately 1000 populations treated, three-fourths apparently successfully, and at least 3 species likely eradicated in the ongoing project. A program to eradicate 29 invasive plant species from Raoul Island, New Zealand, has succeeded for 11 species that infested small areas, while progress on the 7 main targets, all widespread, has been gradual, largely because of the plants' biology and the difficult terrain (West and Thompson 2013). A heavy infestation of Cenchrus echinatus (Poaceae) was eradicated from 64 ha on Laysan Island (Flint and Rehkemper 2002). A prominent claim that a large-scale plant eradication project in the Galápagos Archipelago was a costly failure, with only 4 small infestations of 30 targeted populations actually removed (Gardener et al. 2010), was recently rebutted with data showing that eradication was the goal in only 21 of the attempts, that 8 attempts had succeeded, and that several others would have succeeded and still could with greater but still feasible commitment of resources (Buddenhagen and Tye 2015).

Many authors have noted that a key to success is long-term commitment of resources to an attempt and that the failure of several attempts likely arose from absence of such commitment. For plants, the existence of persistent soil seed banks particularly necessitates long-term commitment. Herbicides and hand-pulling have been almost universally employed in island invasive plant eradication attempts, both those that have succeeded and those that have not. 


\section{Other Taxa}

A smattering of attempts have been made to eradicate other taxa from entire islands but there are too few to summarize success rates and to seek patterns. For snakes, we found only the failed attempt to eradicate the wolf snake (Lycodon aulicus) from the small Île aux Aigrettes off the coast of Mauritius (Rodda et al. 2002). Ongoing attempts to eradicate the brown tree snake (Boiga irregularis) from a small fenced area of Guam have failed so far. Kraus (2009) reports that the Australian frog Limnodynastes dumerilii was eradicated from a small region of the North Island of New Zealand before further spread, and also that the toad Bufo gargarizans was eradicated from a small site in Okinawa before it dispersed further. Bullfrogs (Lithobates catesbeianus) were eradicated from several ponds in southern England (Kraus 2009), and they do not currently occur in the wild in Great Britain. The coqui (Eleutherodactylus coqui) was eradicated from a small area on Oahu before it spread on the island (Beachy et al. 2011), and incursions are suppressed elsewhere in Hawaii (http://www .kauaiisc.org/coqui, accessed 26 September 2017). Nico and Walsh (2011) reviewed several attempts (including a few successes) to eradicate freshwater fishes from various sites on Pacific islands. Massive attempts to eradicate nonnative crayfish from particular rivers in Great Britain have proven futile (Holdich and Pöckl 2007), but a small established population of the Australian hairy marron crayfish (Cherax tenuimanus) was eradicated in New Zealand (Yaldwyn and Webber 2011). New invasions of the giant African snail (Lissachatina fulica) have been eradicated from 2 small Pacific islands, as has a new infestation of the freshwater snail Pila conica in Palau (Cowie 2011).

\section{Benefits of Island Eradications}

Eradications of invasive mammals on islands have yielded enormous conservation returns. A sample of 251 eradications on 181 islands revealed that 596 populations of 236 native island species have benefited (Jones et al. 2016). Eradication of the American mink from Hiiumaa Island, Estonia, was essential to reintroducing the endangered European mink (Mustela lutreola). Many other cases exemplify positive effects of eradicating American mink, including increases in breeding densities of several waterfowl species following removal of the mink from 60 islands and islets of Finland (Nordström et al. 2002) and the increased breeding success of several tern species (Sterna paradisaea, S. hirundo, S. albifrons) following eradication of the same predator in the Outer Hebrides (Roy 2011). Eradication of feral cats (Felis catus) from North West Island, Australia, spurred a population increase in the Buffbanded Rail (Gallirallus philippensis) and the Silver-eye (Zosterops lateralis) (Dickman 1996). In Asuncion and San Roque Islands, Mexico, populations of Cassin's Auklets (Ptychoramphus aleuticus) were extirpated by cat predation (Wolf et al. 2006), but this species recolonized the island after cats were eradicated (FélixLizárraga et al. 2009). Eradication of cats on Natividad Island, Mexico, has dramatically lowered breeding season mortality of the Black-vented Shearwater (Puffinus opisthomelas) (Keitt and Tershy 2003). Removal of Golden Eagles (Aquila chrysaetos) from the northern Channel Islands and eradication of the pigs on Santa Cruz Island that were subsidizing the eagles have spurred recovery of the island fox, Urocyon littoralis (Coonan et al. 2010). Rat eradication on Anacapa Island led to increased abundances of seabirds and marine intertidal invertebrates, as well as 2 seabird species that had likely been extirpated by the rats (Ashy Storm-Petrel [Oceanodroma homochroa] and Cassin's Auklet) now breeding on the island (Newton et al. 2016).

One of many examples of positive outcomes of removing an herbivore (in this instance, an omnivorous one) is the eradication in 1958 of pigs from Clipperton Island (Pacific Ocean) in response to drastic population declines of several bird species. Seabird populations recovered significantly (Lorvelec and Pascal 2005). Eradication of rabbits has aided recovery of certain native plant species on Round Island, Mauritius (North et al. 1994), and Île Verte and Île Guillou in the Kerguelens (Chapuis et al. 2004), but in both instances other native plant populations fell because populations of introduced plants that had been favored by rabbits increased. A similar result has occurred in the wake of goat eradication on several islands (Campbell and Donlan 2005).

\section{Maintenance Management}

Eradication is tempting because, if it succeeds and reinvasion does not occur, management costs for the target species disappear, 
except for those associated with preventing reinvasion. Eradication is particularly seductive on islands because of their smaller size relative to the mainland, suggesting greater feasibility, and relative isolation, which should greatly reduce the probability of rapid reinvasion. Maintenance management, on the other hand, aims not to eradicate a target pest but to maintain it at acceptable levels. Classical biological control, among the 3 common technologies, appears attractive from a cost perspective because, even though development costs may be high (particularly now that nontarget impacts are recognized as a concern), in principle if the project works, no further expenses accrue. The target pest is never extirpated, and if its population increases, it is automatically controlled by an increase in the population of its introduced natural enemy. Most applications have involved agricultural pests, but the technology is increasingly used for conservation purposes (Van Driesche et al. 2016).

A few examples exist of successful biological control of invasive insects on islands with no evidence of substantial nontarget impact. The cottony cushion scale (Icerya purchasi), which threatened many native plants after its arrival in the Galápagos Islands in 1982, has been successfully controlled by the lady beetle Rodolia cardinalis, introduced from 2002 to 2005 (Causton et al. 2016). The endemic coral tree (Erythrina sandwicensis) of Hawaii, a major component of dwindling dry forest, was rescued from devastating attack by an introduced gall wasp (Quadrastichus erythrinae) by quick testing and release of the parasitic wasp Eurytoma erythrinae (Kaufman and Messing 2016). Introduction of the lady beetle Hyperaspis pantherina rapidly controlled the South and Central American scale insect Orthezia insignis, which had threatened the endemic national tree of Saint Helena, Commidendrum robustum (Cock 2003).

Introduced natural enemies have also controlled environmentally damaging invasive plants on islands, for example Cordia curassavica on Mauritius (Fowler et al. 2000) and mistflower (Ageritina riparia) on North Island, New Zealand (Suckling 2013). On Tahiti, an introduced fungus has partially controlled the massive invasion by Miconia calvescens (Loope et al. 2013). The most famous example for both islands and continents is control of New World Opuntia species in Australia by the introduced South American cactus moth Cactoblastis cactorum (Dodd 1940), but using this species against Opuntia on other islands has led to 2 major controversies (Hoddle 2016) relevant to employing biological control in general. This moth successfully controlled Opuntia after it was introduced to the Caribbean island of Nevis (and quickly reached nearby St. Kitts) in 1957 (Pemberton and Liu 2007), but the target species were native rather than introduced. Second, the moth has spread to Florida either on its own or perhaps assisted by hitchhiking on cut flowers, and from Florida it has spread northward and westward, threatening native Opuntia species in North America. The cactus moth has also controlled 2 nonnative Opuntia species on Mauritius (Fowler et al. 2000). The key lesson from these campaigns is to be mindful of the possibility of spread of a control agent to unintended regions. A disturbing element in the discussion of possible nontarget impacts of biological control is the frequent unstated assumption (e.g., Hoddle 2016) that if an introduced natural enemy does not completely eliminate some native species, it is harmless. In fact, society recognizes many impacts far short of extinction as environmental "harm" (Simberloff 2005). It is important to realize also that many biocontrol programs for invasive plants on islands fail, and that a consistent complaint of invasive plant managers (e.g., Fowler et al. 2000, Loope et al. 2013) is inadequate funding for biocontrol programs.

Physical and mechanical methods, either alone or together with herbicides, have often successfully managed invasive plants on islands. The invasive $\mathrm{N}$-fixing tree albizia (Falcataria moluccana) was well controlled by girdling on Tutuila, American Samoa (Hughes et al. 2012) and Silhouette in the Seychelles (Rocamora and Henriette 2017). In the Galápagos Islands, introduced trees Cedrela odorata and Cinchona pubescens were maintained at levels below the threshold of impact by a combination of physical and chemical means (Gardener et al. 2013). Herbicides have locally controlled many invasive plant species on the island of Hawaii (Loope et al. 2013). Effectiveness and nontarget impacts of physical/chemical management of the same plant species vary among islands, and both successes and failures abound. Often mobilization of sufficient personpower and maintenance of an adequate 
budget are critical. Aside from concern with nontarget impacts, expense and the evolution of resistance are frequent issues with herbicides. Many publications detail specific methods and limitations (e.g., Sarat et al. 2015, Rocamora and Henriette 2017).

Long-term maintenance management is often viewed as a second-best alternative when eradication fails. However, it is worth noting that many successful maintenance management programs, especially those using physical, mechanical, and chemical means, were originally planned as eradication attempts. It should also be borne in mind that either incremental or transformative technological advances might enable what had been a maintenance management campaign to achieve complete eradication. This fact, combined with the prospect that lack of management may lead to degradation so severe that restoration becomes extremely difficult (Corbin and D’Antonio 2012), or even impossible when extinctions occur, should give pause when maintenance management is perceived as too costly.

\section{Technical Improvements and Prospects}

The increasing success of mammal eradications has entailed incremental improvements of varying degrees to well-established approaches, such as aerial broadcast of existing anticoagulant toxins. Sometimes the increment allows major scaling up of an eradication attempt to improve its efficacy. One example is sterilization and hormone implants to induce prolonged estrus in female Judas goats (Campbell et al. 2007), an approach that played a key role in goat eradication on the northern part of Isabela Island (Carrion et al. 2011). Additionally, Campbell et al. (2015) identified several approaches in various stages of development that could transform rodent eradication.

For island plant eradication, several novel techniques, some previously applied in eradication programs for mammals, constitute advances that could profitably be more widely employed. The use of helicopters to locate and eradicate plant populations in inaccessible or difficult-to-reach locations has been crucial to the Santa Cruz Island project (Knapp et al. 2012, Cory and Knapp 2014). On Santa Cruz Island, helicopters have also been used with herbicide ballistic technology (Leary et al.
2012) to permit eradications that had previously been intractable. A trained dog on Raoul Island finds infestations that have proven difficult for project staff to access and to detect (Havell 2014). In other invasive plant management programs, dogs have proven more effective than humans at locating targets (e.g., Goodwin et al. 2010). Dogs have been crucial in other eradication projects, such as the long, successful effort to clear Macquarie Island of all nonnative mammals (Beavis and Junt 2014), and experiments have suggested that dogs can be useful parts of island projects to manage or eradicate the small Indian mongoose (Fukuhara et al. 2010) and the brown tree snake, Boiga irregularis (Savidge et al. 2011). Ongoing monitoring for the Argentine ant eradication attempt on Santa Cruz Island employed a dog in 2017 (C.L. Boser, personal communication, 2017).

Novel methods might be profitably employed in maintenance management. In particular, endocrine mimics and disrupters appear to have been used very rarely for environmental or conservation purposes, even though they have an extensive history in managing invasive agricultural and forest insect pests (Reddy and Guerrero 2010), and sex and migratory pheromones are in development for managing the invasive sea lamprey (Petromyzon marinus) in the Great Lakes (Sorensen and Bergstedt 2011). Several of the innovative technologies that Campbell et al. (2015) list in their horizon scan of promising approaches for rodent eradication could also be cost effective and useful for maintenance management, such as virus-vectored immunocontraception and crab deterrents in toxic baits.

Sixty years of intensive use of synthetic insecticides have been marked by substantial ongoing improvement in terms of new chemicals and lower-dose formulations, lower probability of nontarget impacts, better delivery to targets, and increased attention to lowering persistence and long-term direct and indirect effects of sublethal concentrations on nontarget species and entire communities (Guedes et al. 2016). Nevertheless, substantial nontarget problems remain (e.g., Kerr 2017). Similarly, biological control has undergone substantial improvement in its focus on minimizing likelihood of nontarget impacts and increasing probability of substantial control of the target 
(Van Driesche et al. 2016), although room for improvement remains on both counts (Williamson and Fitter 1996, Simberloff 2012a, Cock et al. 2016). Biological control projects have also now moved beyond focus only on direct killing of the target pest. For example, on Christmas Island, the devastating attack by yellow crazy ants (Anoplolepis gracilipes) on the iconic red crab (Gecarcoidea natalis) was stemmed at great expense by periodic helicopter spraying with fipronil (Green and O'Dowd 2009). The ant invasion had been precipitated by introduction of a nonnative scale insect whose honeydew was exploited by the ants, and a new biological control project entails targeting the scale with a parasitoid, Tachariaephagus somervillei (Neumann et al. 2016).

Several recent technological advances in molecular genetics have engendered tremendous enthusiasm about the possibility that formerly intractable invasions might now become manageable or perhaps even eradicated. This prospect has been particularly aggressively explored for insects and fishes (Thresher et al. 2014), but it has also spawned controversies. The ethics of killing sentient organisms and concern about unintended consequences of eliminating a population are not unique to genetic technologies (Simberloff $2012 b)$. However, the idea of heritable change, with its prospect of changing the nature of a species, is new. A genetic technology that would not be heritable is gene-silencing, or RNA interference (RNAi), which entails using double-stranded RNA to destroy messenger RNA, thus blocking transcription. The main development obstacle is getting the doublestranded RNA into the cell, but the fervor for applying this technique to agricultural insect pests and rodents as biomedical models suggests that progress is highly likely (Campbell et al. 2015). Pilot projects on 2 beetle pests of agriculture in enclosed settings have succeeded (Baum et al. 2007, San Miguel and Scott 2016), and the internet has information about gene-silencing projects targeting environmentally problematic animals and plants, though not specifically on islands. In 2017, the U.S. Environmental Protection Agency registered 4 new products-plants genetically modified to produce RNAi that attacks corn rootworm (EPA 2017)—including corn seed expected to be marketed by 2019 (Zhang
2017). An attraction of gene-silencing is that the technique targets specific genes, so it is not only highly species-specific but could even differentiate between an introduced genotype and a native genotype. Furthermore, it could be used even on species reproducing asexually.

The first high-profile case involving a heritable change was that of the genetically modified Aedes aegypti mosquito produced by Oxitec, a British company, to combat dengue and released in field trials on Grand Cayman Island in 2009 (Enserink 2010). Even before the release, the prospect had elicited concern that nations where no releases were planned could be affected and that no international law or treaty adequately encompassed such cases (Angulo and Gilna 2008). Postrelease, the controversy rapidly expanded (Enserink 2010). The transgene of the Oxitec mosquito renders embryos that carry it inviable, so the heritability concern was muted. The advent of Zika virus, transmitted by the same mosquito, quickly overtook proposals for treaties and profound discussions of ethics. A leading venture capitalist purchased Oxitec (Pollack 2016), and the Oxitec mosquito is now being massproduced and widely released in Piracicaba, Brazil, with plans to release billions of individuals in that nation alone (Servick 2016). Voters in Monroe County (the Florida Keys), where plans to release the Oxitec mosquito to combat dengue and yellow fever had long been contested, approved the release in the wake of the rapidly developing threat of Zika in Florida (Langston 2016), but the U.S. Food and Drug Administration, faced with a lawsuit from citizens and one town arguing that testing for potential impacts had been insufficient, canceled plans for the release (DanleyGreiner 2017).

The advent of RNA-guided gene drives, particularly those using the 2015 Science "Breakthrough of the Year" (Travis 2015), CRISPR-Cas9, has particularly excited both geneticists and invasion managers, with several lines of attack sketched out for how gene drives could greatly improve prospects for both maintenance management and eradication of invasive populations (Esvelt et al. 2014). The technology is more accessible than that employed to produce the Oxitec mosquito, and CRISPR-Cas9 in particular is even more accessible than earlier gene drives. 
Gene drives can work only on sexually reproducing organisms, and the speed with which a driven gene spreads depends on the generation length of the organism; thus, a long-lived species that reaches sexual maturity late would be a less promising target, unless the conservation goal were formulated in a very long-term framework. Because of their life histories, invertebrates, small mammals such as rodents, fishes, and many plants would seem to be possible targets. However, any autocidal gene will immediately stimulate natural selection to counter its impact. In fact, Hamilton (1967), in an early suggestion of how such driven alleles might be used to control pests, pointed out that an allele distorting sex ratios or destroying one sex (the basis of several RNA-guided gene drive proposals) would generate such strong selection on genes elsewhere in the genome (particularly on different chromosomes) that these would either quickly counteract the impact of the guided gene or the population would go extinct. Such extinctions might have happened in the past with naturally arising driven genes.

There is thus a race between the spreading, driven, detrimental gene and natural selection in the rest of the genome to counteract it. If eradication is the goal, the circumstances under which a gene drive might succeed would be a relatively small population that would thus have fewer existing or new mutant antagonistic genes to combat the driven one. And the scenario would also be advantageous if this smaller, more restricted population were isolated, so immigrants carrying such genes would be less likely. In short, an island population would seem to be a propitious target. Esvelt et al. (2014) suggest that if a driven gene fails to eradicate a target, one could simply release another one, and then another, in effect turning the technique into a maintenance management approach. However, in the earliest stages of evaluating the efficacy of the entire gene drive approach, the idea of Esvelt et al. (2014) seems at best tentative and unproven.

\section{Discussion}

Successful control of invasive nonnative species on islands has a long history and, despite the ongoing arrival of new invaders, the likelihood of success has continued to improve, with more species and larger and more complex islands becoming feasible targets. Challenges of course remain-for example, eradication of rodents on tropical islands (Russell and Holmes 2015), eradication of plants (Simberloff 2013c), and costs and nontarget effects of sustained maintenance management when eradication is not (yet) an option. However, the entire enterprise of controlling island invasions is marked by both incremental improvement of existing technologies and occasional "quantum innovations" that greatly improve chances of controlling particular species or entire classes of them.

Gene drives may be just such a quantum innovation. However, the possibility of using gene drives for invasion management has led to far more concerted concern, and even outright opposition, than the occasional opposition to previous management projects (e.g., Simberloff 2012b), largely because the modified genes will not only be heritable but can be designed to be autocidal-that is, to spread to the detriment of the population even to the point of extinction. For some projects where nonnative species eradication has been identified as a priority conservation strategy, some observers have already begun recommending genetic solutions if a safe, proven tool can be developed (Esvelt et al. 2014, Campbell et al. 2015). One such recommendation involves house mice on the Farallon Islands in San Francisco Bay (Hawkes 2016), where previous proposals to use toxic baits had aroused enormous opposition based on concerns about animal welfare, animal rights, and nontarget impacts of chemicals. A group of prominent conservation and environmental activists released the statement "A Call for Conservation with a Conscience: No Place for Gene Drives in Conservation" (http://www.etcgroup .org/files/files/final_gene_drive_letter.pdf, accessed 2 October 2016) at the World Conservation Congress in September 2016, calling for a permanent ban on any attempt to use the technique in a conservation context.

In this instance, the horse has probably already left the barn. Science magazine routinely includes an advertisement from OriGene for "CRISPER/CAS 9 Genome Editing Kits" that will "Knock Out Any Gene," while Cyagen Biosciences spammed many scientists on 9 January 2017 with an advertisement for "big savings" on rat and mouse models for CRISPR 
Knockout, Knockin, and Point Mutation models. Jennifer Doudna, cofounder of the technology, has recently published CRISPR-Cas: A Laboratory Manual, which includes stepby-step protocols for applying CRISPR-Cas techniques to several animal systems (Doudna and Mali 2016). Jon Cohen, a Science reporter, asking whether "any idiot can do it," attempted an application under guidance, and he apparently meant to calm concern by concluding that "any idiot cannot do CRISPR" (Cohen 2016). However, he immediately undercut his message by adding that "it takes, at least, basic laboratory skills." The current situation is reminiscent of the early days of application of basic PCR and Taq polymerase methods to amplify DNA segments in the 1980s, an approach that quickly became utterly routine for anyone with "basic laboratory skills."

The prospect of heritable genetic manipulation and consequent population extinction has led to many proposals for caution and broad consideration of the venture's ethical underpinnings as well as the possible unintended consequences, not least by researchers developing the technology (e.g., Oye et al. 2014, Baltimore et al. 2015). The United States National Academy of Sciences (2016) urged caution and continued research but not releases to the environment at this time. A general concern, aside from unintended direct and indirect consequences of eliminating a species, is the possibility of a gene drive somehow being inserted into the genome of a nontarget organism, although there is no scientific evidence to date to suggest this is likely to happen. Another issue is the possibility of drastic and even irrevocable actions by "rogue" players as gene drive technology becomes increasingly accessible. Thus, despite the potential for strong selection against gene drive-mediated infertility, caution is warranted.

It has often been noted that simply removing or managing an invasive species does not constitute ecological restoration of an island and may even create foreseen or unforeseen impediments (e.g., Zavaleta et al. 2001). Removing an herbivore may allow hitherto suppressed nonnative plants to dominate, as happened initially with fennel (Foeniculum vulgare) when livestock were removed from Santa Cruz Island (Dash and Gliessman 1994). Removal of nonnative invasive plants has often led to a "treadmill effect" in which another nonnative plant becomes dominant (Thomas and Reid 2007). Removing one nonnative predator may release a previously suppressed predator, as on several islands where rat eradication precipitated a population explosion of house mice (Caut et al. 2007). Incremental improvements in eradication and management technologies and the prospect of transformative new approaches, such as gene drives, particularly suited for use on islands should inspire optimism that island biotas can be saved and island ecosystems restored. However, increased understanding of the complex nature of interactions among species suggests that, as Zavaleta et al. (2001) argued, eradication and management of island invasives should be undertaken in a whole-ecosystem context. To an extent this is already happening, as manifested by the increase in mammal eradications targeting multiple species and invasive weed removal accompanied by seeding with native species. However, the prospect of larger and more complex projects becoming increasingly feasible makes the need to understand community interactions and ecosystem functioning, and to account for them, even more urgent.

\section{ACKNOWLEDGMENTS}

We thank 2 anonymous reviewers of an earlier draft of the manuscript for substantial constructive comments and criticisms.

\section{Literature Cited}

Angulo, E., AND B. GILNA. 2008. International law should govern release of GM mosquitoes. Nature 454:158.

ANONYmous. 2015. Red-whiskered Bulbul eradicated from Seychelles. SIF [Seychelles Island Foundation] Newsletter, January (Issue 27).

Ashmole, N.P., M.J. Ashmole, and K.E.L. Simmons. 1994. Seabird conservation and feral cats on Ascension Island, south Atlantic. Pages 94-121 in D.N. Nettleship, J. Burger, and M. Gochfield, editors, Seabirds on islands: threats, case studies and action plans. BirdLife International, Cambridge, United Kingdom.

Baltimore, B.D., P. Berg, M. Botchan, D. Carroll, R.A. Charo, G. Church, J.E. Corn, G.Q. Daley, J.A. Doudna, M. Fenner, ET AL. 2015. A prudent path forward for genomic engineering and germline gene modification. Science 348:36-38.

Barun, A., K.C. Campbell, C.C. Hanson, and D. SimBERLOFF. 2011. A review of the small Indian mongoose management and eradications on islands. Pages 17-25 in C.R. Veitch, M.N. Clout, and D.R. Towns, editors, Island invasives: eradication and 
management. Manaaki Whenua Press, Auckland, New Zealand.

Baum, J.A., T. Bogaert, W. Clinton, G.R. Heck, P. Feldmann, O. Ilagan, S. Johnson, G. Plaetinck, T. Munyikwa, M. Plead, et al. 2007. Control of coleopteran insect pests through RNA interference. Nature Biotechnology 25:1322-1326.

Baumhover, A.H., A.J. Graham, B.A. Bitter, D.E. HopKINS, W.D. NEW, F.H. DUdLEY, AND R.C. BuCHLAND. 1955. Screw-worm control through release of sterilized flies. Journal of Economic Entomology 48: 462-466.

Beachy, J.R., R. Neville, and C. ARnotT. 2011. Successful control of an incipient invasive amphibian: Eleutherodactylus coqui on O'ahu, Hawai'i. Pages 140-147 in C.R. Veitch, M.N. Clout, and D.R. Towns, editors, Island invasives: eradication and management. Proceedings of the International Conference on Island Invasives. IUCN, Gland, Switzerland; The Centre for Biodiversity and Biosecurity (CBB), Auckland, New Zealand.

BEAVIS, L., AND L. JunT. 2014. Macquarie Island declared pest free after 7-year eradication program. ABC AU News; [accessed April 2014]. http://www.abc.net .au/news/2014-04-07/macquarie-island-declared -pest-free-after-eradication-program/5373336

Boser, C.L. 2016. Argentine ant eradication on Santa Cruz Island [online Prezi presentation]. Posted 12 January 2016; accessed 11 January 2017. https:// prezi.com/amls43y0se-s/argentine-ant-eradication -on-santa-cruz-island

Boser, C.L., C. Hanna, K.R. Faulkner, C. Cory, J.M. Randall, AND S.A. Morrison. 2014. Argentine ant management in conservation areas: results of a pilot study. Monographs of the Western North American Naturalist 7:518-530.

Buddenhagen, C.E., And A. Tye. 2015. Lessons from successful plant eradications in Galapagos: commitment is crucial. Biological Invasions 17:2893-2912.

Buhs, J.B. 2004. The fire ant wars. University of Chicago Press, Chicago, IL.

[CDFW] California Department of Fish and WildLIFE. 2015. California State Wildlife Action Plan, 2015 update: a conservation legacy for Californians. A.G. Gonzales and J.Hoshi, editors. Prepared with assistance from Ascent Environmental, Inc. CDFW, Sacramento, CA.

Campbell, K.J., G.S. Baxter, P.J. Murray, B.E. CoblentZ, and C.J. Donlan. 2007. Development of a prolonged estrus effect for use in Judas goats. Applied Animal Behaviour Science 102(1-2):12-23.

Campbell, K., J. Beek, C.T. Eason, A.S. Glen, J. Godwin, F. Gould, N.D. Holmes, G.R. Howald, F.M. Madden, J.B. Ponder, ET AL. 2015. The next generation of rodent eradications: innovative technologies and tools to improve species specificity and increase their feasibility on islands. Biological Conservation 185:47-58

Campbell, K., and C. Donlan. 2005. Feral goat eradications on islands. Conservation Biology 19:1362-1374.

Carrion, V., C.J. Donlan, K.J. Campbell, C. Lavoie, and F. CRUZ. 2011. Archipelago-wide island restoration in the Galapagos Islands: reducing costs of invasive mammal eradication programs and reinvasion risk. PLOS ONE 6(5):e18835.

Carson, R. 1962. Silent spring. Houghton Mifflin, Boston, MA.
Causton, C., M.S. Hoddle, and R.G. Van Driesche. 2016. Protecting Galápagos plants from cottony cushion scale. Pages 215-220 in R. Van Driesche, D. Simberloff, B. Blossey, C. Causton, M. Hoddle, C. Marks, K. Heinz, D. Wagner, and K. Warner, editors, Integrating biological control into conservation practice. Wiley-Blackwell, Chichester, United Kingdom.

Caut, S., J.G. Casanovas, E. Virgos, J. Lozano, G.W. Witmer, and F. Courchamp. 2007. Rats dying for mice: modelling the competitor release effect. Austral Ecology 32:858-868.

Chapuis, J.-L., Y. Frenot, and M. Lebouvier. 2004. Recovery of native plant communities after eradication of rabbits from the subantarctic Kerguelen Islands, and influence of climate change. Biological Conservation 117:167-179.

Civeyrel, L., and D. Simberloff. 1996. A tale of two snails: is the cure worse than the disease? Biodiversity and Conservation 5:1231-1252.

Clout, M.N., AND P.A. Williams, EDITORS. 2009. Invasive species management. Oxford University Press, New York, NY.

Cock, M.J.W. 2003. Risks of non-target impact versus stakeholder benefits in classical biological control of arthropods: selected case studies from developing countries. Pages 25-33 in R.G. Van Driesche, editor, Proceedings of the International Symposium on Biological Control of Arthropods, Honolulu, Hawaii, 14-18 January 2002. United States Department of Agriculture, Forest Service, Morgantown, WV.

Cock, M.J.W., S.T. Murphy, M.T.K. KaIRo, E. Thompson, R.J. Murphy, and A.W. Francis. 2016. Trends in the classical biological control of insect pests by insects: an update of the BIOCAT database. BioControl 61:349-363.

Cohen, J. 2016. A reporter does CRISPR. Science $354: 541$

Coonan, T.J., C.A. Schwemm, and D.K. Garcelon. 2010. Decline and recovery of the island fox: a case study for population recovery. Cambridge University Press, Cambridge, United Kingdom.

Corbin, J.D., And C.M. D'Antonio. 2012. Gone but not forgotten? Invasive plants' legacies on community and ecosystem properties. Invasive Plant Science and Management 5:117-124.

Cory, C., AND J.J. Knapp. 2014. A program to eradicate twenty-four nonnative invasive plant species from Santa Cruz Island. Monographs of the Western North American Naturalist 7:455-464.

CowIE, R.H. 2011. Snails and slugs. Pages 634-643 in D. Simberloff and M. Rejmánek, editors, Encyclopedia of biological invasions. University of California Press, Berkeley, CA.

Cruz, F., C.J. Donlan, K. Campbell, and V. Carrion. 2005. Conservation action in the Galapagos: feral pig (Sus scrofa) eradication from Santiago Island. Biological Conservation 121:473-478.

Dahlsten, D.L. 1986. Control of invaders. Pages 275-302 in H.A. Mooney and J.A. Drake, editors, Biological invasions of North America and Hawaii. SpringerVerlag, New York, NY.

DANLEY-GreineR, K. 2017. FDA backs down from releasing genetically modified mosquitoes after lawsuit threatened [online]. Florida Record, The Record Inc., Rolling Meadows, IL; [posted 8 January 2017; accessed 26 September 2017]. http://flarecord.com/ stories/511066542-fda-backs-down-from-releasing 
-genetically-modified-mosquitoes-after-lawsuitthreatened

Dash, B., And S. Gliessman. 1994. Non-native species eradication and native species enhancement: fennel on Santa Cruz Island. Pages 505-512 in W. Halvorson and G. Maender, editors, The Fourth California Islands Symposium: update on the status of resources. Santa Barbara Museum of Natural History, Santa Barbara, CA.

Dickman, C.R. 1996. Overview of the impacts of feral cats on Australian native fauna. Australian Nature Conservation Agency, Canberra, Australia.

DIISE Partners. 2014. The database of island invasive species eradications. Developed by Island Conservation, Coastal Conservation Action Laboratory UCSC, IUCN SSC Invasive Species Specialist Group, University of Auckland and Landcare Research New Zealand. http://diise.islandconservation.org

DiTomaso, J.M. 2011. Herbicides. Pages 323-331 in D. Simberloff and M. Rejmánek, editors, Encyclopedia of biological invasions. University of California Press, Berkeley, CA.

DoDD, A.P. 1940. The biological campaign against prickly-pear. Commonwealth Prickly Pear Board, Sherwood, Australia.

Doudna, J., AND P. MaLI, Editors. 2016. CRISPR-Cas: a laboratory manual. Cold Spring Harbor Laboratory Press, Cold Spring Harbor, NY.

Drake, J.A., H.A. Mooney, F. DiCastri, R.H. Groves, F.J. Kruger, M. Rejmánek, and M. Williamson, EDITORS. 1989. Biological invasions: a global perspective. Wiley, Chichester, United Kingdom.

Elton, C.E. 1958. The ecology of invasions by animals and plants. Methuen, London.

EnserinK, M. 2010. GM mosquito trial alarms opponents, strains ties in Gates-funded project. Science 330: $1030-1031$.

[EPA] Environmental Protection Agency. 2017. EPA registers innovative tool to control corn rootworm [online]. News releases from headquarters, EPA Press Room; [posted 15 June 2017; accessed 27 September 2017]. https://www.epa.gov/newsreleases/ epa-registers-innovative-tool-control-corn-root worm

Esvelt, K.M., A.L. Smidler, F. Catteruccia, and G.M. Church. 2014. Concerning RNA-guided gene drives for the alteration of wild populations. eLife 10.7554/ eLife.03401

Félix-Lizárraga, M., A. Aguirre-Muñoz, B. Keitt, and H. Berlanga-García. 2009. Restauración de aves marinas en islas del Pacífico de Baja California con sistemas de atracción social. Memorias del Encuentro Nacional para la Conservación y el Desarrollo Sustentable de las Islas de México. 23-26 June 2009. Ensenada, B.C., México.

Flint, E.N., And C. Rehkemper. 2002. Control and eradication of the introduced grass, Cenchrus echinatus, at Laysan Island, central Pacific Ocean. Pages 110-115 in C.R. Veitch and M.N. Clout, editors, Turning the tide: the eradication of invasive species. IUCN SSC Invasive Species Specialist Group, IUCN, Gland, Switzerland.

Fowler, S.V., S. Ganshan, J. Mauremootoo, and Y. Mungroo. 2000. Biological control of weeds in Mauritius: past successes revisited and present challenges. Pages 43-50 in N.R. Spencer, editor, Proceedings of the $\mathrm{X}$ International Symposium on
Biological Control of Weeds. Montana State University, Bozeman, MT.

Fukuhara, R., T. Yamaguchi, H. Ukuta, S. Roy, J. Tanaka, and G. Ogura. 2010. Development and introduction of detection dogs in surveying for scats of small Indian mongoose as invasive alien species. Journal of Veterinary Behavior 5:101-111.

Gardener, M.R., R. AtKinson, and J.L. Rentería. 2010. Eradications and people: lessons from the plant eradication program in Galapagos. Restoration Ecology 18:20-29.

Gardener, M.R., M. Trueman, C. Buddenhagen, R. Heleno, H. Jäger, R. Atkinson, And A. Tye. 2013. A pragmatic approach to the management of plant invasions in Galápagos. Pages 349-374 in L. Foxcroft, D.M. Richardson, P. Pyšek, and P. Genovesi, editors, Alien plant invasions in protected areas: patterns, problems, and challenges. Springer, Dordrecht, Netherlands.

Genovesi, P., AND L. Carnevali. 2011. Invasive alien species on European islands: eradication and priorities for future work. Pages 56-62 in C.R. Veitch, M.N. Clout, and D.R. Towns, editors, Turning the tide: the eradication of invasive species. Manaaki Whenua Press, Auckland, New Zealand.

Glen, A., R. Atkinson, K. Campbell, E. Hagen, N. Holmes, B. Keitt, J.P. Parkes, A. Saunders, J. SAWYer, AND H. TorRes. 2013. Eradicating multiple invasive species on inhabited islands: the next big step in island restoration? Biological Invasions 15 : 2589-2603.

Goodwin, K.M., R.E. Engel, and D.K. Weaver. 2010. Trained dogs outperform human surveyors in the detection of rare spotted knapweed (Centaurea stoebe). Invasive Plant Science and Management 3:113-121.

Green, P.T., AND D.J. O’Dowd. 2009. Management of invasive invertebrates: lessons from the management of an invasive alien ant. Pages 153-172 in M.N. Clout and P.A. Williams, editors, Invasive species management. Oxford University Press, New York, NY.

Griffiths, R., F. Buchanan, K. Broome, and B. ButLAND. 2012. Rangitoto and Motutapu - a starting point for future vertebrate pest eradications on inhabited islands. Pages 22-27 in R. Timm and R.A. Baldwin, editors, Proceedings of the 25th Vertebrate Pest Conference, Monterey, CA.

Guedes, R.N.C., G. Smagghe, J.D. Stark, and N. Desneux. 2016. Pesticide-induced stress in arthropod pests for optimized integrated pest management programs. Annual Review of Entomology 61:43-62.

Hadjisterkotis, E., and P.M. Heise-Pavlov. 2006. The failure of the introduction of wild boar Sus scrofa in the island of Cyprus: a case study. European Journal of Wildlife Research 52:213-215.

Hamilton, W.D. 1967. Extraordinary sex ratios. Science 156:477-488.

Havell, D. 2014. Persistence and detection of weed locations in some northern New Zealand island weed programmes. Pages 383-386 in M. Baker, editor, Proceedings of the Nineteenth Australasian Weeds Conference. Tasmanian Weed Society, Hobart, Tasmania.

Hawkes, A. 2016. Re-coding for conservation. Bay Nature, July-September. http://baynature.org/article/ re-coding-conservation 
Herms, D.A., and D.G. McCullough. 2011. Pesticides for insect eradication. Pages 528-535 in D. Simberloff and M. Rejmánek, editors, Encyclopedia of biological invasions. University of California Press, Berkeley, CA.

Hoddle, M.S. 2016. Forecasting unintended effects of natural enemies used for classical biological control of invasive species. Pages 130-160 in R. Van Driesche, D. Simberloff, B. Blossey, C. Causton, M. Hoddle, C. Marks, K. Heinz, D. Wagner, and K. Warner, editors, Integrating biological control into conservation practice. Wiley-Blackwell, Chichester, United Kingdom.

Hoelmer, K.A., AND J.K. Grace. 1989. Citrus blackfly. Pages 147-165 in D.L. Dahlsten and R. Garcia, editors, Eradication of exotic pests. Yale University Press, New Haven, CT.

Hoffmann, B., G.M. Luque, C. Bellard, N.D. Holmes, AND C.J. Donlan. 2016. Improving invasive ant eradication as a conservation tool: a review. Biological Conservation 198:37-49.

Holdich, D.M., aND M. PöCKL. 2007. Invasive crustaceans in European inland waters. Pages 29-75 in F. Gherardi, editor, Biological invasions in inland waters: profiles, distribution, and threats. Springer Dordrecht, Netherlands.

Hooker, J.D. 1867. Insular floras. Gardeners' Chronicle, January. http://www.wku.edu/ smithch/biogeog/ HOOK1866.htm

Hughes, R.F., A.L. Uowolo, and T.P. Togia. 2012 Recovery of native forest after removal of an invasive tree, Falcataria moluccana, in American Samoa. Biological Invasions 14:1393-1413.

InNes, J., AND A. SAUnders. 2011. Eradicating multiple pests: an overview. Pages 177-181 in C.R. Veitch, M.N. Clout, and D.R. Towns, editors, Island invasives: eradication and management. Proceedings of the International Conference on Island Invasives. IUCN, Gland, Switzerland; The Centre for Biodiversity and Biosecurity (CBB), Auckland, New Zealand.

Jones, H.P., N.D. Holmes, S.H.M. Butchart, B.R. TerShy, P.J. Kappes, I. Corkery, A. Aguirre-Muñoz, D.P. Armstrong, E. Bonnaud, A.A. Burbidge, and K. Campbell. 2016. Invasive mammal eradication on islands results in substantial conservation gains. Proceedings of the National Academy of Sciences (USA) 113:4033-4038.

Kaufman, L., and R.H. Messing. 2016. Preserving Hawaiian dry forests by protecting wiliwili trees from Erythrina gall wasps. Pages 220-223 in R. Van Driesche, D. Simberloff, B. Blossey, C. Causton, M. Hoddle, C. Marks, K. Heinz, D. Wagner, and K. Warner, editors, Integrating biological control into conservation practice. Wiley-Blackwell, Chichester, United Kingdom.

Kean, J.M., D.M. Suckling, N.J. Sullivan, P.C. Tobin, L.D. Stringer, G.R. Smith, B. Kimber, D.C. Lee, R. Flores Vargas, J. Fletcher, ET AL. 2017. Gerda: global eradication and response database. [Accessed 12 January 2017]. http://b3.net.nz/gerda

Keitt, B., K. Campbell, A. Saunders, M.N. Clout, Y. Wang, R. Heinz, K. Newton, and B. Tershy. 2011. The Global Islands Invasive Vertebrate Eradication Database: a tool to improve and facilitate restoration of island ecosystems. Pages 74-77 in C.R Veitch, M.N. Clout, and D.R. Towns, editors, Island invasives: eradication and management. Manaaki Whenua Press, Auckland, New Zealand.

Keitt, B., And B. Tershy. 2003. Cat eradication significantly decreases shearwater mortality. Animal Conservation 6:307-308

KERR, J.T. 2017. A cocktail of poisons. Science 356: 1331-1332.

KLassen, W., And C.F. CuRTis. 2005. History of the sterile insect technique. Pages 3-36 in V.A. Dyck, J. Hendrichs, and A.S. Robinson, editors, Sterile insect technique: principles and practice in area-wide integrated pest management. Springer, Dordrecht, Netherlands.

Knapp, J.J., P.T. Schuyler, K.N. Walker, N.L. MacdonALD, AND S.A. MorRISON. 2012. Benefits of supporting invasive plant and animal eradication projects with helicopters. Pages 188-191 in C.R. Veitch, M.N. Clout, and D.R. Towns, editors, Island invasives: eradication and management. Manaaki Whenua Press, Auckland, New Zealand.

Kraus, F. 2009. Alien reptiles and amphibians: a scientific compendium and analysis. Springer, Dordrecht, Netherlands.

LAngston, E. 2016. Voters in this Florida county just approved GM mosquitoes to fight Zika. [Accessed 13 November 2016]. http://www.motherjones.com/ environment/2016/11/key-haven-monroe-county -florida-gm-mosquitos-2016-election

Lapeyssonie, L. 1988. La médecine coloniale. Seghers, Paris, France.

Leary, J.K., J. Gooding, A. Radford, B. Mahnken, J. Chapman, G. Kaiser, C. Cory, and J. Knapp. 2012. Operational performance of a herbicide ballistic technology (HBT) helicopter platform targeting incipient populations of miconia (Miconia calvescens) in Hawaiian watersheds [abstract]. California Invasive Plant Council 2012 Symposium, Rohnert Park, CA.

Lever, C. 2001. The cane toad. Westbury, Otley, United Kingdom.

Loope, L.L., R.F. Hughes, AND J.-Y. Meyer. 2013. Plant invasions of protected areas of tropical Pacific islands, with special reference to Hawaii. Pages 313-348 in L. Foxcroft, D.M. Richardson, P. Pyšek, and P. Genovesi, editors, Alien plant invasions in protected areas: patterns, problems, and challenges. Springer, Dordrecht, Netherlands.

Lorvelec, O., ANd M. Pascal. 2005. French attempts to eradicate non-indigenous mammals and their consequences for native biota. Biological Invasions 7: 135-140.

Macdonald, D.W., and L.A. Harrington. 2003. The American mink: the triumph and tragedy of adaptation out of context. New Zealand Journal of Zoology 30:421-441

MaLOY, O.C. 1997. White pine blister rust control in North America: a case history. Annual Review of Phytopathology 35:87-109.

Mooney, H.A., and J.A. Drake, EDitors. 1986. Biological invasions of North America and Hawaii. SpringerVerlag, New York, NY

Morrison, S.A., A.J. DeNicola, K. Walker, D. Dewey, L. Laughrin, R. Wolstenholme, and N. MacdonALD. 2016. An irruption interrupted: eradication of Wild Turkeys Meleagris gallopavo from Santa Cruz Island, California. Oryx 50:121-127. 
Neumann, G., D.J. O’Dowd, P.J. Gullan, and P.T. Green. 2016. Diversity, endemism and origins of scale insects on a tropical oceanic island: implications for management of an invasive ant. Journal of AsiaPacific Entomology 19:159-166.

Newton, K.M., M. McKown, C. Wolf, H. Gellerman, T. Coonan, D. Richards, A.L. Harvey, N.D. Holmes, G. Howald, K. Faulkner, et al. 2016. Response of native species ten years after rat eradication on Anacapa Island, California. Journal of Fish and Wildlife Management 7:72-85.

NICO, L.G., AND S.J. WaLSH. 2011. Non-indigenous freshwater fishes on tropical Pacific islands: a review of eradication efforts. Pages 97-107 in C.R. Veitch, M.N. Clout, and D.R. Towns, editors, Island invasives: eradication and management. Proceedings of the International Conference on Island Invasives. IUCN, Gland, Switzerland; The Centre for Biodiversity and Biosecurity (CBB), Auckland, New Zealand.

Nordström, M., J. Högmander, and J. Nummelin. 2002. Variable responses of waterfowl breeding populations to long-term removal of introduced American mink. Ecography 25:385-394.

North, S.G., D.J. Bullock, AND M.E. Dulloo. 1994. Changes in the vegetation and reptile populations on Round Island, Mauritius, following eradication of rabbits. Biological Conservation 67:21-28.

Oppel, S., B.M. Beaven, M. Bolton, J. Vickery, and T.W. BODEY. 2011. Eradication of invasive mammals on islands inhabited by humans and domestic animals. Conservation Biology 25:232-240.

Oye, K.A., K. Esvelt, E. Appleton, F. Catteruccia, G. Church, T. Kuiken, S.B. Lightfoot, J. McNamara, A. Smidler, AND J.P. Collins. 2014. Regulating gene drives. Science 345:626-628.

PARKES, J. 2008. A feasibility study for the eradication of house mice from Gough Island. Royal Society for the Preservation of Birds Report No. 34. Sandy, Bedfordshire, United Kingdom.

Pemberton, R.W., and H. Liu. 2007. Control and persistence of native Opuntia on Nevis and St. Kitts 50 years after the introduction of Cactoblastis cactorum. Biological Control 41:272-282.

Petersen, A.E. 1979. The breeding birds of Flatey and some adjoining islets in Breidafjördur in NW Iceland. Náttúrufr 49:229-256. [In Icelandic with English summary.]

Pollack, A. 2016. A biotech evangelist seeks a Zika dividend. New York Times, 6 March 2016, page BU1.

Reddy, G.V., AND A. Guerrero. 2010. New pheromones and insect control strategies. Vitamins and Hormones 83:493-519.

Rejmánek, M., And M.J. Pitcairn. 2002. When is eradication of exotic pest plants a realistic goal? Pages 249-253 in C.R. Veitch and M.N. Clout, editors, Turning the tide: the eradication of invasive species. IUCN SSC Invasive Species Specialist Group, IUCN, Gland, Switzerland.

Ritchie, J. 1920. The influence of man on animal life in Scotland: a study in faunal evolution. Cambridge University Press, Cambridge, United Kingdom.

Rocamora, G., and E. Henriette. 2017. Invasive alien species in Seychelles. University of Chicago Press, Chicago, IL.

Rodda, G.H., T.H. Fritts, E.W. Campbell III, K. DeanBradley, G. Perry, and C.P. Qualls. 2002. Practical concerns in the eradication of island snakes. Pages
260-265 in D. Veitch and M. Clout, editors, Turning the tide: eradication of invasive species. Invasive Species Specialist Group of the World Conservation Union (IUCN), Auckland, New Zealand.

Roy, S. 2011. Strategies to improve landscape scale management of mink populations in the west coast of Scotland: lessons learned from the Uists 2001-2006. Pages 114-117 in C.R. Veitch, M.N. Clout, and D.R. Towns, editors, Island invasives: eradication and management. Manaaki Whenua Press, Auckland, New Zealand.

Russell, J.C., And N.D. Holmes. 2015. Tropical island conservation: rat eradication for species recovery. Biological Conservation 185:1-7.

San Miguel, K., AND J.G. ScotT. 2016. The next generation of insecticides: dsRNA is stable as a foliarapplied insecticide. Pest Management Science 72: 801-809.

Sarat, E., E. Mazaubert, A. Dutarte, N. Poulet, and Y. SOUBEYRAN, EDITORs. 2015. Les espèces exotiques envahissantes dans les milieux aquatiques. Volume 2, Expériences de gestion. Office National de l'Eau et des Milieux Aquatiques, Vincennes, France.

Savidge, J.A., J.W. Stanford, R.N. ReEd, G.R. Haddock, AND A.A. YACKEL ADAms. 2011. Canine detection of free-ranging brown treesnakes on Guam. New Zealand Journal of Ecology 35:174-181.

Scottish Natural Heritage. 2013. Hebridian Mink Project, Introduction - Phase 1 and Phase 2. Scottish Natural Heritage, Inverness, Scotland.

Servick, K. 2016. Winged warriors. Science 354:164-167.

SimberlofF, D. 2005. Non-native species do threaten the natural environment! Journal of Agricultural and Environmental Ethics 18:595-607.

Simberloff, D. 2011a. SCOPE project. Pages 617-619 in D. Simberloff and M. Rejmánek, editors, Encyclopedia of biological invasions. University of California Press, Berkeley, CA.

SimberlofF, D. 2011b. Charles Elton-neither founder nor siren, but prophet. Pages 11-24 in D.M. Richardson, editor, Fifty years of invasion ecology. Wiley, New York, NY.

Simberloff, D. 2012a. Risks of biological control for conservation purposes. BioControl 57:263-276.

SimberlofF, D. 2012b. Nature, natives, nativism, and management: worldviews underlying controversies in invasion biology. Environmental Ethics 34:5-25.

SimberLofF, D. 2013a. Biological invasions: much progress plus several controversies. Contributions to Science 9:7-16.

SimberlofF, D. 2013b. Invasive species. What everyone needs to know. Oxford University Press, New York, NY.

SimberlofF, D. 2013c. Eradication-pipe dream or real option? Pages 549-559 in L. Foxcroft, D.M. Richardson, P. Pyšek, and P. Genovesi, editors, Alien plant invasions in protected areas: patterns, problems, and challenges. Springer, Dordrecht, Netherlands.

Sorensen, P.W., and R.A. Bergstedt. 2011. Sea lamprey. Pages 619-623 in D. Simberloff and M. Rejmánek, editors, Encyclopedia of biological invasions. University of California Press, Berkeley, CA.

South Georgia Heritage Trust. 2016. The South Georgia habitat restoration project: final report. South Georgia Heritage Trust, Dundee, Scotland.

SPEAR, R.J. 2005. The great gypsy moth war. University of Massachusetts Press, Amherst, MA. 
SuckLing, D.M. 2013. Benefits from biological control of weeds in New Zealand range from minimal to massive: a retrospective analysis. Biological Control 66: $27-32$.

Thomas, M.B., AND A.M. REID. 2007. Are exotic natural enemies an effective way of controlling invasive plants? Trends in Ecology and Evolution 22: 447-453.

Thomson, G., AND S. EbBert. 2005. Eradication of arctic foxes with incidental wildlife observations at Attu Island, Alaska in 1999. U.S. Fish and Wildlife Service report AMNWR 05/03, Homer, AK.

Thomson, G.M. 1922. The naturalisation of animals and plants in New Zealand. Cambridge University Press, Cambridge, United Kingdom.

Thresher, R.E., K. Kayes, N.J. BaX, J. Teem, T.J. Benfey, AND F. GOULD. 2014. Genetic control of invasive fish: technological options and its role in integrated pest management. Biological Invasions 16:1201-1216.

Tobin, P.C., J.M. Kean, D.M. Suckling, D.G. McCulLough, D.A. Herms, and L.D. Stringer. 2014. Determinants of successful arthropod eradication programs. Biological Invasions 16:401-414.

Towns, D.R., And K.G. Broome. 2003. From small Maria to massive Campbell: forty years of rat eradications from New Zealand islands. New Zealand Journal of Zoology 30:377-398.

Travis, J. 2015. Making the cut. Science 350:1456-1457.

United States National ACademy of Sciences. 2016. Gene drives on the horizon. National Academies Press, Washington, DC.

Urich, J.W. 1931. The mongoose in Trinidad. Tropical Agriculture 8:95-97.

Van Driesche, R., M. Hoddle, and T. Center. 2008. Control of pests and weeds by natural enemies. Blackwell, Malden, MA.

Van Driesche, R., D. Simberloff, B. Blossey, C. Causton, M. Hoddle, C. Marks, K. Heinz, D. WaGNER, AND K. WARNER, EDITORS. 2016. Integrating biological control into conservation practice. WileyBlackwell, Chichester, United Kingdom.

Veitch, D., And M. Clout, EDitors. 2002. Turning the tide: eradication of invasive species. Invasive Species Specialist Group of the World Conservation Union (IUCN), Auckland, New Zealand.

Veitch, C.R., M.N. Clout, and D.R. Towns, editors, 2011. Island invasives: eradication and management. Proceedings of the International Conference on Island Invasives. Manaaki Whenua Press, Auckland, New Zealand.

VINCE, G. 2011. Embracing invasives. Science 331: $1383-1384$.

WaLLaCE, A.R. 1880. Island life. Macmillan, London.

Watson, J., C. Warman, D. TodD, and V. Laboudallon. 1992. The Seychelles Magpie Robin Copsychus sechellarum: ecology and conservation of an endangered species. Biological Conservation 61:93-106.

Wenner, A.M., R.W. Thorp, and J.F. Barthell. 2009. Biological control and eradication of feral honey bee colonies on Santa Cruz Island, California: a summary. Pages 327-335 in C.C. Damiani and D.K. Garcelon, editors, Proceedings of the 7th California Islands Symposium. Institute for Wildlife Studies, Arcata, CA.

West, C.J., And A.M. Thompson. 2013. Small, dynamic, and recently settled: responding to the impact of plant invasions in the New Zealand (Aotearoa) Archipelago. Pages 285-311 in L. Foxcroft, D.M. Richardson, P. Pyšek, and P. Genovesi, editors, Alien plant invasions in protected areas: patterns, problems, and challenges. Springer, Dordrecht, Netherlands.

Wetterer, J.K., and S.D. Porter. 2003. The little fire ant, Wasmannia auropunctata: distribution, impact, and control. Sociobiology 42:1-41.

Whisson, D.A. 2011. Pesticides (mammal). Pages 535-539 in D. Simberloff and M. Rejmánek, editors, Encyclopedia of biological invasions. University of California Press, Berkeley, CA.

Williamson, M., AND A. FitTer. 1996. The varying success of invaders. Ecology 77:1661-1666.

Wolf, S., B. Keitt, A. Aguirre-Muñoz, B. Tershy, E. Palacios, and D. Croll. 2006. Transboundary seabird conservation in an important North American marine ecoregion. Environmental Conservation 33: 294-305.

YadaV, R.P., and A. Singh. 2011. Pesticides (fish and mollusc). Pages 525-527 in D. Simberloff and M. Rejmánek, editors, Encyclopedia of biological invasions. University of California Press, Berkeley, CA.

YaLdWYn, J.C., AND W.R. WebBer. 2011. Annotated checklist of New Zealand Decapoda (Arthropoda: Crustacea). Tuhinga 22:171-272.

Zavaleta, E.S., R.J. Hobbs, and H.A. Mooney. 2001. Viewing invasive species removal in a wholeecosystem context. Trends in Ecology and Evolution 16:454-459.

ZHANG, S. 2017. The EPA quietly approved Monsanto's new genetic-engineering technology [online]. The Atlantic, Science Section; [posted 23 June 2017, accessed 27 September 2017]. https://www.the atlantic.com/science/archive/2017/06/monsanto-rna -interference/ $/ 531288$

Received 26 February 2017

Revised 28 September 2017

Accepted 19 December 2017

Published online 22 October 2018 